ite pteropod shells is shallower than that of the last glacial period. At the present time the compensation level of pteropod shells is at a depth of about $2,000 \mathrm{~m}$, whereas the compensation depth was more than $3,000-4,000 \mathrm{~m}$ in the Wisconsin period.

I thank W. Broecker, J. Hays and N. Hillman for their help and C. Emiliani and D. Ericson for allowing me to present their unpublished data. I also thank C. Emiliani and E. Degens for enabling me to examine their cores. This research was sponsored by a grant from the US National Science Foundation. The cores were obtained during expeditions sponsored by the US Navy, Office of Naval Research and the National Science Foundation.

Chin Chen

Lamont Geological Observatory,

Columbia University,

Palisades, New York.

Received July 15; revised August 15, 1968.

'Ericson, D. B., Ewing, M., Wollin, G., and Heezen, B. C., Bull. Geol. Soe. Amer., 72, 193 (1961)

${ }^{2}$ Ericson, D. B., Ewing, M., aud Wolli., G., Science, 146, 723 (1964).

${ }^{3}$ Blackman, A., and Somayajulu, B. L. K., Science, 154, 886 (1966).

${ }^{4}$ Lidz, L., Science, 154, 1448 (1966).

${ }^{5}$ Emiliani, C., J. Geol., 63, 538 (1955).

'Emiliani, C., Bull. Geol. Soc. Amer., 75, 129 (1964).

${ }^{7}$ Emiliani, C., Science, 154, 851 (1966).

s Murray, J., and Renard, A., Deep-sea Deposits (Rep. Sei. Res. "Challenger". 1891).

${ }^{9}$ Sverdrup, H. U., Johnson, M. W., and Fleming, R. H., The Oceans (Prentice-Hall, NY, 1942).

10 Curry, D., in Micropaleontology of the Oeeans (edit. by Seibold and Funnell) (University of Cambridge Press, in the press)

${ }^{11}$ Pelseneer, P., Rep. Voy. Challenger Zool., 23, 1 (1888).

12 Chen, C., Science, 144, 60 (1964).

${ }^{13}$ Rehder, H. A., US Geol. Surv. Prof. Paper, 196, 107 (1942).

${ }^{14}$ Hanzawa, S., Rec. Oceanog. Works in Japan, 1, 59 (1928).

${ }^{15}$ Stubbings, H. G., John Murray Exped. Sci. Rep., 3, 31 (1939).

${ }^{16}$ Ericson, D. B., Ewing, M., and Wollin, G., Science, 144, 1183 (1964).

12 Ros snberg-Herman, Y., Ann. Inst. Oceanog. Monaco, 42, 339 (1965).

${ }^{18}$ Erieson, D. B., and Wollin, G., Micropaleontol., 2, 257 (1956).

${ }^{18}$ Suess, H. E., Science, 123, 355 (1956).

${ }^{20}$ Berggren, W., and Boersma, A., in Hot Brines and Recent Heavy Mineral Deposits in the Red Sea (edit. by Degens, E. T., and Ross, D. A.) (Springer Verlag, New York, in the press).

${ }^{21}$ Deuser, W., and Degens, E., in Hot Brines and Recent Heavy Mineral Deposits in the Red Sea (edit. by Degens, E. T., and Ross, D. A.) (Springer Verlag, New York, in the press).

${ }^{22} \mathrm{Ku}, \mathrm{T}$. L., in Hot Brines and Recent Heavy Mineral Deposits in the Red Sea (edit. by Degens, E. T., and Ross, D. A.) (Springer Verlag, New York, in the press).

\section{Concentrations of Radon-222 in Coal Mines in England and Scotland}

IN the past few years, a number of measurements have been made of radon-222 concentrations in mines other than uranium mines ${ }^{1-4}$. The values found, expressed in picocuries of radon per litre of air, ranged from $0 \cdot 2 \mathrm{pCi} / \mathrm{l}$. (a value typical of that occurring in the atmosphere) to several hundred $\mathrm{pCi} / \mathrm{l}$., and it was therefore considered worthwhile making similar measurements in various British coal mines. Measurements have been made in twelve mines chosen from the East Midlands, Kent and Scottish coalfields.

Samples of air were obtained from various occupied areas in each mine and then taken to the Radiological Protection Service laboratory for content of radon to be measured. The sample was transferred to a vessel containing a zinc sulphide screen held at a negative potential. The decay of the radon atoms produces positively charged radium-A atoms which are attracted to the sereen, and the radon concentration is determined from the number of $\alpha$-particles emitted by the radium-A and radium- $C^{\prime}$ atoms. The method has been described in detail elsewhere $^{5}$. The sampling carried out in the first two mines visited (mines $A$ and $B$ ) was repeated after an interval of about 4 months and it was found that, for each mine, the concentration did not vary with location in the mine or with time by much more than a factor of two. Concentrations of radon in the other coal mines investigated were therefore assessed from a smaller number of occupied areas.

The ranges of radon concentrations found in each of the mines visited are shown in Table 1 .

\begin{tabular}{|c|c|c|}
\hline \multicolumn{3}{|c|}{ Table 1} \\
\hline Coalfield & Mine & $\begin{array}{l}\text { Range of radon } \\
\text { concentrations (pCi/1.) }\end{array}$ \\
\hline East Midlands & $\underset{B}{A}$ & $\begin{array}{l}5-12 \\
4-11 \\
2-3\end{array}$ \\
\hline Kent & $\begin{array}{l}D \\
E \\
F \\
F\end{array}$ & $\begin{array}{l}1 \cdot 4-3 \\
1 \cdot 6-3 \\
0 \cdot 8-2\end{array}$ \\
\hline Scotland & $\begin{array}{l}G \\
H \\
I \\
J \\
K \\
K \\
\end{array}$ & $\begin{array}{l}1 \cdot 3-2 \\
0 \cdot 9-2 \\
0 \cdot-1 \cdot 2 \\
3-14 \\
1 \cdot 3 \\
1 \cdot 0-1 \cdot 7\end{array}$ \\
\hline
\end{tabular}

The median concentration for the twelve mines is about 2 pCi/l., a value very close to that found by Lucas and Gabrysh for Pennsylvanian coal mines".

Concentrations of radon in uranium mines are typically two orders of magnitude greater than the concentrations reported here, and there seems little doubt that uranium miners suffer from an incidence of lung cancer related to their exposure to radon ${ }^{6}$. There is no evidence that concentrations of radon of the magnitude found in British coal mines give rise to an increased incidence of lung cancer. The incidence of lung cancer among British coal miners has been shown to be appreciably lower than the national incidence for men of comparable ages ${ }^{7,8}$.

Measurements of concentrations of radon in other British mines are now being carried out.

We thank Dr E. A. C. Chamberlain, the director of Scientific Control, National Coal Board, without whose permission and help these measurements would not have been possible.

\section{J. DugGan \\ D. M. HOWELL \\ P. J. SollleuX}

Radiological Protection Service,

Clifton Avenue,

Sutton, Surrey.

Received July $12,1968$.

${ }^{1}$ Jacoe, B. W., Arch. Indust. Hyg., 8, 118 (1953).

${ }^{2}$ Harris, S. J., Arch. Indust. Hyg., 10, 54 (1954).

${ }^{3}$ De Villiers, A. J., and Windish, J. P., Brit. J. Indust. Med., 21, 94 (1964).

"Lucas, H. F., and Gabrysh, A. F., Radon in Coal Mines, ANL-7060 (1966). ${ }^{5}$ Vennart, J., Maycock, G., Godfrey, B. E., and Davies, B. L., Proc. Symp. on
Assessment of Radioactivity in Man, Heidelberg, 1964,'2, 277 (Intern. Atomic Energy Agency, Vienna, 1965).

- Staff Report No. 8 of the Federal Radiation Council (1967).

'Doll, R., Brit. J. Indust. Med., 15, 217 (1958).

${ }^{8}$ Goldman, K. P., Brit. J. Indust. Med.,22, 72 (1965).

\section{Extraction of Meaningful Kinetic Para- meters from Thermogravimetric Analysis}

MucH effort is being devoted to thermo-analytical techniques such as thermogravimetric analysis (TGA) ${ }^{1-3}$, differential thermal analysis (DTA) ${ }^{4-6}$ and differential enthalpic analysis (DEA ${ }^{7}$, in order to evaluate kinetic parameters for solid state decompositions of the generic type

$$
A(\mathrm{~s}) \rightarrow B(\mathrm{~s})+C(\mathrm{~g})
$$

It is generally accepted ${ }^{8,9}$ that such reactions, which are often characteristic of polymer degradations and the decomposition of inorganic complexes and minerals, begin at certain discrete regions, called nucleus-forming sites, 